\title{
TBX3 wt Allele
}

National Cancer Institute

\section{Source}

National Cancer Institute. TBX3 wt Allele. NCI Thesaurus. Code C101639.

Human TBX3 wild-type allele is located in the vicinity of 12 q24.1 and is approximately 14 $\mathrm{kb}$ in length. This allele, which encodes T-box transcription factor TBX3 protein, plays a role in both transcriptional regulation and anterior/posterior axis development. Mutation of the gene is associated with ulnar-mammary syndrome. 